\title{
Welfare Changes and Sectoral Adjustments of Asia-Pacific Countries under Alternative Sequencings of Free Trade Agreements
}

\author{
Ken Itakura \\ Graduate School of Economics \\ Nagoya City University, Nagoya 467-8501, Japan \\ Hiro Lee ${ }^{\dagger}$ \\ Osaka School of International Public Policy \\ Osaka University, Osaka 560-0043, Japan
}

1 March 2012

\begin{abstract}
In recent years, a growing number of bilateral and plurilateral free-trade agreements (FTAs) involving Asia-Pacific countries have been signed, ratified, or under negotiations. Although there have been studies on sequencing of real and monetary integration, studies comparing changes in welfare and industrial structure resulting from different sequencings of FTAs are extremely scarce. In this paper we compare welfare effects and the extent of sectoral adjustments of the member countries under two alternative FTA sequencings in the Asia-Pacific region, Asian-track and Trans-Pacific-track sequencings, using a dynamic computable general equilibrium (CGE) model. Under the assumption that both an East Asian FTA (EAFTA) and Trans-Pacific Partnership (TPP) agreement will enter into force in 2013, followed by more enlarged FTAs, most member countries are expected to realize larger welfare gains under the Asian track. With respect to sectoral adjustments, there appear to be no significant differences between the two sequencings. A further investigation is required to consider the possibility of delays in EAFTA.
\end{abstract}

JEL classification: F15, F17

Keywords: Sequencing, FTA, Asia-Pacific, CGE model

\footnotetext{
† Corresponding author. Osaka School of International Public Policy, Osaka University, 1-31 Machikaneyama, Toyonaka, Osaka 560-0043, Japan. Email: hlee@osipp.osaka-u.ac.jp
} 


\section{Introduction}

In the past decade, a growing number of bilateral and plurilateral free-trade agreements (FTAs) involving Asia-Pacific countries have been signed or ratified. For example, the ASEAN countries have implemented FTAs with six major trading partners in the region - China, Japan, Korea, India, and Australia/New Zealand - while they aim to create a single market (ASEAN Economic Community) across the 10 member states by 2015. Korea became the first country to sign an FTA with the EU under the "Global Europe” initiative, and the EU-Korea FTA entered into force in July 2011. The creation of an East Asian community and Free Trade Area of the Asia Pacific (FTAAP) has been proposed by leaders of several Asia-Pacific countries in recent years. Whether the growth of FTAs has a positive or negative impact on multilateral trade liberalization under the WTO has been debated intensely (e.g., Krueger, 1999; Panagariya, 2000; Lloyd and MacLaren, 2004).

A number of studies have quantified the effects of various FTAs in the Asia-Pacific region using a computable general equilibrium (CGE) model (e.g., Kawai and Wignaraja, 2008; Lee et al., 2004, 2009; Lee and van der Mensbrugghe, 2008; Park, 2006; Urata and Kiyota, 2005). In addition, there have been studies on the sequencing of real and monetary integration (e.g., Baldwin, 2008; Kreinin and Plummer, 2009). In contrast, studies on industrial adjustments and consequent optimum sequencing of FTAs are extremely scarce. Bond (2008) considers the relationship between adjustment costs and sequencing of trade liberalization, such as the elimination of tariffs, liberalization of financial markets, and adoption of common policies, but not the sequencing of FTAs. However, the magnitudes of sectoral output and employment adjustments resulting from different FTAs will be a great concern to policy makers. In this paper, we will shed light on the relationship between sequencing of FTAs and the extent of industrial adjustments for Asia-Pacific countries.

In this paper, we compare two alternative sequencings of FTAs in the Asia-Pacific region, namely (1) ASEAN+3 FTA (East Asia Free Trade Area: EAFTA), followed by ASEAN+6 FTA (Comprehensive Economic Partnership in East Asia: CEPEA) and 
FTAAP, and (2) TPP9, followed by TPP13 and FTAAP. ${ }^{1}$ Using a global dynamic CGE model, we examine whether one is more advantageous than the other in terms of welfare gains and industrial adjustments. This requires three steps. We first establish the baseline scenario for the period up to 2030. Second, for each scenario of FTA sequencing, we compute changes in economic welfare and the extent of sectoral output adjustments of the member countries relative to the baseline. Third, we calculate the rank correlation between the extent of adjustments under each FTA sequencing and the extent of adjustments that would prevail under global trade liberalization (GTL). If a particular FTA sequencing would change the industrial structure within each country closer to that which would prevail under free trade, while increasing economic welfare of the member countries, then that FTA sequencing may be considered as a facilitating intermediate step towards GTL.

The next section gives an overview of the model and data. Section 3 provides a brief description of the baseline and policy scenarios, followed by assessments of computational results in section 4 . The final section offers conclusions and possible extensions of the paper.

\section{Analytical Framework and Data}

\subsection{Overview of the Dynamic GTAP Model}

The numerical simulations undertaken for this study are derived from the Dynamic GTAP model, described in detail by Ianchovichina and McDougall (2001). This model extends the comparative static framework of the standard GTAP model developed by Hertel (1997) to the dynamic framework by incorporating international capital mobility and capital accumulation. In the standard static GTAP model, capital can move across industries within a region, but not across regions or countries. For a long-run analysis to be more realistic, the model requires a mechanism to capture incentives to invest in different regions, thereby allowing international capital mobility and capital accumulation.

\footnotetext{
1 The members of TPP9 are Australia, Brunei, Chile, Malaysia, New Zealand, Peru, Singapore, United States and Vietnam. The members of TPP13 consist of the members of TPP9, plus Canada, Japan, Korea and Mexico.
} 
The Dynamic GTAP model preserves all the features of the standard GTAP, such as constant returns to production technology, perfectly competitive markets, and product differentiation by countries of origin, in keeping with the so-called Armington assumption. $^{2}$ At the same time, it enhances the investment theory by incorporating international capital mobility and ownership. In this way it captures important FTA effects on investment and wealth that are missed by a static model.

In the Dynamic GTAP model, each of the regions is endowed with fixed physical capital stock owned by domestic firms. The physical capital is accumulated over the time with new investment. This dynamics is driven by the net investment, which is sourced by regional households' savings. Regional households own indirect claims on the physical capital in the form of equity. There are two types of equities: equity in domestic firms and equity in foreign firms. The households directly own the domestic equity but only indirectly hold the foreign equity. To access equity in foreign firms, the households must own shares in a portfolio of foreign equities provided by the "global trust" that is assumed to be the sole financial intermediary for all foreign investments. The values of the households' equity holdings in domestic firms and in the global trust evolve over the time, and the households allocate all their savings for investment. Collecting such investment funds across regions, the global trust reinvests the funds in firms around the world and offers a portfolio of equities to households. The sum of households' equity holdings in the global trust is equal to the global trust's equity holdings in firms around the world.

The savings in one region are invested directly in domestic firms and indirectly in foreign firms through the global trust, which are in turn reinvested in all regions. The dynamics arising from positive savings in one region is related to the dynamics from the net investment in other regions. Overall, at the global level, it must hold that all the savings across regions are completely invested in home and overseas markets.

\footnotetext{
2 See Armington (1969). The model uses a nested CES structure, where at the top nested level, each agent chooses to allocate aggregate demand between domestically produced goods and an aggregate import bundle, while minimizing the overall cost of the aggregate demand bundle. At the second level, aggregate import demand is allocated across different trading partners, again using a CES specification, wherein the aggregate costs of imports are minimized.
} 
In theory, incentives for investments or equity holdings are governed by the rates of return, which will be equalized across regions if capital is perfectly mobile. However, an equalization of the rates of return seems unrealistic, at least in the short run. In addition, there exist well-known empirical observations for "home bias" in savings and investment and households' equity holdings. The observations suggest that the capital is not perfectly mobile, causing some divergence in the rates of return across regions. The dynamic GTAP model allows inter-regional differences in the rates of return in the short run, which will be eventually equalized in the very long run. This may be regarded as a realistic approach, but it calls for a mechanism to allocate equity holdings of the households and the global trust in a way consistent with the observed data. It is assumed that differences in the rates of return are attributed to the errors in investors' expectations about the future rates of return. During the process, these errors are gradually adjusted to the actual rate of return as time elapses. Eventually the errors are eliminated and a unique rate of return across regions can be attained.

While perfect capital mobility is assumed only in the very long run, investment is induced by a gradual movement in the expected rate of return toward an equality across regions. The expected rate of return may differ from the actual rate of return due to errors in expectations. Explicit modeling of the ownership of regional investment allows one to determine the accumulation of wealth by foreigners. In addition, the ownership of domestic and foreign assets can also be tracked. Income accruing from the ownership of the foreign and domestic assets can then be appropriately incorporated into total regional income.

Participating in an FTA could lead to more investment from abroad. Trade liberalization often makes prices of goods in a participating country lower due to removal of tariffs, creating an increase in demand for the goods. Responding to the increased demand, production of the goods expands in the member country. The expansion of production is attained by using more intermediate inputs, labor, capital, and other primary factor inputs. These increased demands for production inputs raise the corresponding prices, wage rates, and rental rates. Higher rental rates are translated into higher rates of return, attracting more investment from both home and foreign countries. 


\subsection{Data, aggregation, and initial tariffs}

In this study we employ the GTAP version 7.1 database, which has a 2004 base year and distinguishes 112 countries/regions and 57 sectors (Narayanan and Walmsley, 2008). For the purposes of the present study, the data has been aggregated to 22 countries/regions and 29 sectors, as shown in Table 1. Foreign income data are obtained from the International Monetary Fund (IMF)'s Balance of Payments Statistics, which are used to track international capital mobility and foreign wealth. The values of key parameters, such as demand, supply and CES substitution elasticities, are based upon the previous empirical estimates. The model calibration primarily consists of calculating share and shift parameters to fit the model specifications to the observed data, so as to be able to reproduce a solution for the base year.

The sectoral tariff rates for the 22 countries/regions in 2004 are summarized in Table 2. There are striking differences in the tariff structures across the countries/regions. Singapore is duty free with the exception of alcohol and tobacco. In Japan, Korea and Taiwan, the extraordinarily high tariff rates on rice particularly stand out. The tariff rates in a number of other agricultural and food products are also high in these three countries as well as in India. With the exception of Australia, New Zealand and Chile, the tariff rates on some agricultural and food products are also relatively high in other regions, such as sugar in Indonesia, the Philippines, the United States and the EU, meats in Thailand, Canada and the rest of the world, and dairy products in the United States and Canada. In manufacturing the tariff rates on textiles and apparel are relatively high in all regions except Singapore, Chile and the EU. The rates on motor vehicles are quite high in China, Taiwan, Malaysia, Thailand, Vietnam, and the rest of ASEAN.

Ad valorem tariff equivalents of nontariff barriers (NTBs) in eight services sectors are computed from the gravity-model estimates of Wang et al. (2009). There are even greater variations in tariff equivalents of NTBs in services than in commodities. 


\section{The Baseline and Policy Scenarios}

\subsection{The Baseline Scenario}

In order to evaluate the effects of various sequencing of FTAs, the baseline scenario is first established, showing the path of each of the 22 economies/regions over the period 2004-2030. The baseline contains information on macroeconomic variables as well as expected policy changes. The macroeconomic variables in the baseline include projections for real GDP, gross investment, capital stocks, population, skilled and unskilled labor, and total labor. Real GDP projections were obtained from IMF's World Economic Outlook Database (September 2011). The data on gross fixed capital formation were acquired from IMF's IFS Online. Projections for population were taken from U.S. Census Bureau's International Data Base, while those for labor were obtained from International Labor Organisation (ILO)’s Economically Active Population Estimates and Populations.

The projections for population, investment, skilled labor and unskilled labor obtained for over 150 countries were aggregated, and the growth rates were calculated to obtain the macroeconomic shocks describing the baseline. Changes in the capital stocks were not imposed exogenously, but were determined endogenously as the accumulation of projected investment. Any changes in real GDP not explained by the changes in endowments are attributed to technological change.

In addition, policy projections are also introduced into the baseline. The policies included in the baseline are those which are already agreed upon and legally binding, including the ASEAN Free Trade Area (AFTA), the ASEAN-China, ASEAN-Korea, ASEAN-Japan, ASEAN-Australia-New Zealand and ASEAN-India FTAs.

\subsection{Policy Scenarios}

Welfare and sectoral output effects of alternative sequencing of FTAs are to be evaluated here. The following two scenarios, as well as the global trade liberalization (GTL) scenario, are designed: 
Scenario 1 (EAFTA-CEPEA-FTAAP scenario): EU-Korea FTA, Korea-US FTA, and ASEAN+3 FTA (EAFTA) over the period 2013-2016, ASEAN+6 FTA (CEPEA) over the period 2017-2022, and FTAAP over the period 2023-2030.

Scenario 2 (TPP-FTAAP scenario): EU-Korea FTA, Korea-US FTA, and TPP9 over the period 2013-2016, TPP13 over the period 2017-2022, and FTAAP over the period 2023-2030.

GTL: Global trade liberalization over the period 2013-2030.

It is assumed that tariff rates on commodities decline linearly to zero and tariff equivalents of NTBs in service are reduced by 25 percent during the periods in consideration among the member countries. One can design an infinite number of scenarios, but we have chosen to compare between the EAFTA-CEPEA-FTAAP scenario (Asian track) and the TPP-FTAAP scenario (TPP track) to examine which scenario is more attractive to Asia-Pacific countries. In both scenarios, the EU-Korea and Korea-US FTAs are assumed to be implemented by 2016. EAFTA is followed by CEPEA and FTAAP in Scenario 1, while TPP9 is followed by TPP13 and FTAAP in Scenario 2.

Petri et al. (2011) also compare between Asian track and Trans-Pacific track of FTAs. There are, however, two notable differences between their scenarios and ours. First, we have a slightly longer time periods (2013-2030 versus 2012-2025) to allow for more gradual implementation of region-wide FTAs. Second, they assume that in the Asian track an FTA among China, Japan and Korea is implemented first, followed by EAFTA and FTAAP. We assume that a China-Japan-Korea (CJK) FTA is unlikely to be realized mainly because there are territorial disputes between China and Japan regarding Senkaku / Diaoyutai Islands, and those between Japan and Korea concerning Takeshima / Dokdo islets. In addition, China-Korea and China-Japan fisheries disputes in recent years have become another source of political tension involving the three countries. It is assumed in this paper that an ASEAN+3 FTA is more likely to be realized than a CJK FTA.

Three caveats should be borne in mind when interpreting the results presented in the next section. First, investment liberalization among the member countries are not considered because it requires the data on foreign direct investment (FDI) flows by source and host countries and industry, which are unavailable. A challenging extension of the 
paper would be to endogenize FDI flows to consider attraction of these flows to developing member countries, which may have a significant impact, as were the cases of Mexico joining NAFTA in 1994 and Spain and Portugal joining the EU in 1986. Second, NTBs in manufacturing are not incorporated in this study due to a lack of reliable empirical estimates. NTBs also exists in a number of manufacturing sectors, including automobiles, pharmaceutical products, and some of food products. In these products regulatory and other barriers, such as stringent standards and testing and certification procedures, exist. Thus, reductions of NTBs in manufacturing are expected to enlarge the benefits of the FTAs. Third, we do not incorporate compliance cost associated with rules of origin (ROOs), nor the cost-mitigating effect arising from consolidating FTAs. As smaller FTAs are consolidated, the harmful "noodle bowl" effects - caused by different FTAs having different ROOs and varying coverage - can be mitigated. The compliance cost eventually becomes zero when all countries participate in a trade agreement because there will be no ROOs under global trade liberalization (GTL). These issues are left for future research.

\section{Empirical Findings}

\subsection{Welfare Effects of Alternative Sequencing of FTAs}

Economic welfare is largely determined by four factors: (1) allocative efficiency, (2) the terms of trade, (3) the contribution to equivalent variation (EV) of change in the price of capital investment goods, and (4) the contribution to EV of change in equity owned by a region. The fourth factor is determined by the change in equity income from ownership of capital endowments, and it can be further decomposed into three parts: a change in the domestic capital stock, a change in household income earned on capital abroad, and a change in the domestic capital owned by foreigners.

With respect to these four factors, the direction of a welfare change may be summarized as follows. The allocative efficiency effect is generally positive for members of consolidated FTAs such as those examined in this paper. This effect is particularly large

for a country with high average initial tariffs. However, it may become negative when the extent of trade diversion is considerably large in FTAs with relatively low intraregional 
trade. The terms-of-trade effect is usually positive for the members with low average initial tariffs and negative for those with high initial tariffs. An increase in the price of capital investment goods generally raises welfare. A welfare change resulting from a change in the equity holdings is positive if the sum of the region's foreign income receipts and an increase in the domestic capital stock is greater than the foreign income payment, and vice versa.

The welfare results for the two policy scenarios, as percentage point deviations in equivalent variation from the baseline for the years 2020, 2025 and 2030, are summarized in Table 3. Under the EAFTA-CEPEA-FTAAP scenario (Asian track), the welfare level of all ASEAN+3 member countries increases in 2020-2030, whereas that of all APEC members (regions 1-20 less the rest of ASEAN and India) increases in 2030. The welfare gains of APEC countries range from $0.6 \%$ (United States) to 13.5\% (Vietnam), which are comparable to the findings by Petri et al. (2011). Small economies with high initial tariffs, high trade/GDP ratios, and large trade shares with the member countries gain the most in percentage terms. For example, Vietnam's initial tariffs are high (Table 2), its exports/GDP and imports/GDP ratios (respectively 59\% and 72\% in 2009) are very large, and the shares of imports from ASEAN+3, ASEAN+6 and APEC countries in its total trade - projected to be $69 \%, 73 \%$ and $83 \%$, respectively, for the year 2013 in the baseline - are among the highest in East Asia. Consequently, Vietnam is expected to realize the largest welfare gains in relative terms in 2020-30 under this scenario. Other countries with greater than 5\% projected gains in 2030 include Korea, Indonesia, Thailand, India and Russia. Taiwan is not a member of the ASEAN+3 or ASEAN+6 grouping, and its welfare is predicted to fall by $1.5 \%$ in 2020 largely because the shares of its trade with these regions is high (58-62\% of its total trade) and the extent of trade diversion would be large. Thus, it has strong incentive to convince the other APEC members of the benefits of FTAAP, as its welfare is projected to increase by $4.5 \%$ in 2030 when FTAAP is assumed to be fully implemented.

Under the TPP-FTAAP scenario (TPP track), economic welfare of several nonmember regions decreases slightly in 2020. Seven countries, namely Japan, Korea, Singapore, Malaysia, Vietnam, Australia and New Zealand, are both ASEAN+6 and TPP13 members. Other than New Zealand, these countries' welfare gains in 2020 are 
smaller under the TPP-FTAAP scenario, which is largely caused by substantially smaller trade with TPP members than trade with ASEAN+6 members (see the Appendix Table). For example, Vietnam's exports to TPP13 and ASEAN+6 regions are projected to constitute respectively $34.5 \%$ and $63.7 \%$ of its total exports, while its imports from these regions are projected to comprise 36.6\% and 73.1\% of its total imports in 2013.

The comparison of welfare changes between the two scenarios appears to suggest that East Asian economies other than Taiwan would be better off pursuing EAFTA and CEPEA rather than following TPP. However, our welfare results are based on the assumption that EAFTA and TPP9 will start in the same year (2013). While TPP9 countries have held eleven rounds of negotiations as of March 2012, no time frame has been proposed for negotiations of region-wide FTAs in Asia. Thus, we do not know whether EAFTA and/or CEPEA will be implemented in the not too distant future. If enlargements of TPP eventually lead to FTAAP, then most East Asian countries are expected to realize relatively large welfare gains by $2030 .^{3}$

\subsection{Sectoral Output Adjustments and the Spearman Rank Correlation Coefficients}

Structural adjustments and resource reallocations result from trade policy changes. The sequencings of FTAs and differences in the initial tariff rates across sectors play a critical role in determining the direction of the adjustments in sectoral output. Other factors that affect the magnitude and direction of output adjustments for each product category include the import-demand ratio, the export-output ratio, the share of each imported intermediate input in total costs, and the elasticity of substitution between domestic and imported products. 4

\footnotetext{
3 Under the TPP-FTAAP scenario, India is expected to incur small losses because it is not a member of TPP13 or FTAAP. However, if TPP and FTAAP are open to new member countries such as India, Cambodia, Laos and Myanmar, then all economies in the region are expected to benefit.

4 A sector with a larger import-demand ratio generally suffers from proportionately larger output contraction through greater import penetration when initial tariff levels are relatively high. In contrast, a sector with a higher export-output ratio typically experiences a larger extent of output expansion, as a result of the removal of tariffs in the member countries. The share of imported intermediate inputs in the total cost of a downstream industry (e.g., the share of imported textiles in the cost of the apparel industry) would evidently affect the magnitude and direction of output adjustments in the latter sector. Finally, the greater the values of substitution elasticities between domestic and imported products, the
} 
Table 4 presents the Spearman rank correlation coefficients between sectoral adjustment rankings in 2020 and 2025, between rakings in 2025 and 2030 for each scenario, as well as the Spearman rank correlation coefficients between sectoral adjustment in each scenario and GTL for the year 2030. For the economies included in both ASEAN+6 and TPP13 groupings, differences in the Spearman rank correlation coefficients under the EAFTA-CEPEA-FTAAP scenario and under the TPP-FTAAP scenario are negligible except Japan. In Japan output adjustments rankings for other transportation, metal and chemical products are among the top six sectors under GTL, but these sectors' rankings move down considerably (to 15th-24th) under the TPP-FTAAP scenario in 2030. A more careful examination is needed to determine reasons why the rankings differ significantly between the Asian-track and TPP-track scenarios for some countries in 2030, when FTAAP is assumed to be fully implemented in both scenarios.

For the countries that are members of ASEAN+6 but not members of TPP13 (i.e. China, Indonesia, the Philippines, Thailand, the rest of ASEAN and India), the Spearman rank correlation coefficients are greater for the EAFTA-CEPEA-FTAAP scenario. For the countries that are members of TPP13 but not members of ASEAN+6, only the United States is included in Table 4 for illustration (Canada, Mexico, Chile and Peru will be included in a revised version). For the United States, the Spearman rank correlation coefficients are significantly greater under the TPP track between the rankings in 2020 and in 2025, as well as between the rankings in 2025 and 2030, than under the Asian track.

Under the Asian track, output of machinery and electronic equipment increases in China, Korea, Indonesia, Malaysia, the Philippines, Thailand, Vietnam and India. For these countries, intra-ASEAN+6 trade in machinery and electronic equipment comprise very large shares of the total trade in these products. Thus, production networks in these products are likely to play an even more important role under the region-wide FTAs, further bolstering investment and fostering transfer of technology. ${ }^{5}$ Output of agricultural sectors fall significantly in Japan and Korea, while that of motor vehicles increase greater the sensitivity of the import-domestic demand ratio to changes in the relative price of imports, thereby magnifying the effects of FTAs.

5 Since the Dynamic GTAP model does not incorporate the FDI-productivity effect, an inclusion of such effect is left for future research. 
considerably in these countries. Output of textiles and apparel increase substantially in China, Indonesia, Thailand and Vietnam, and that of most services sectors increase in Singapore, Australia and New Zealand.

Under the TPP track, changes in sectoral output in Japan, Korea, Singapore, Malaysia, Vietnam, Australia and New Zealand are relatively similar to those under the Asian track. For China, Indonesia, the Philippines, Thailand, the rest of ASEAN and India, the magnitudes of changes in sectoral output are significantly smaller under the TPP track in 2020 and 2025. In the United States, output of rice, livestock, meats, other food products, petroleum products and all services sectors would expand, while most manufacturing sectors are expected to contract.

The correlations between sectoral adjustment rankings in 2020 and 2025, as well as between rakings in 2025 and 2030, for both the EAFTA-CEPEA-FTAAP and TPP-FTAAP scenarios are generally high, and both FTA sequencings tend to change the industrial structure within each member country closer to that which would prevail under global trade liberalization. Neither the Asian track scenario nor the TPP track scenario would divert the industrial structure of member countries from that which is projected under multilateral free trade. Nevertheless, some sectors in several countries, including rice, other grains and meats in Japan and Korea, and textiles and apparel in the United States, Australia and New Zealand are expected to contract substantially by 2030 if no domestic reforms aimed at increasing competitiveness of these sectors are carried out. For nonmember countries, low rank correlations are no cause for concern because percentage changes in sectoral output are quite small. For either scenario, FTAs that are open to new member countries are particularly attractive.

\section{Conclusion}

In this paper, we have used the Dynamic GTAP model to investigate how two alternative sequencings of FTAs in the Asia-Pacific region might affect the welfare changes and sectoral output adjustments. Under the assumption that both an ASEAN+3 FTA and TPP9 agreement will enter into force in 2013, followed by more enlarged FTAs, most member countries are expected to realize larger welfare gains under the Asian track. 
However, since no time frame has been proposed for negotiations of ASEAN+3 FTA or ASEAN+6 FTA, region-wide FTAs in Asia may be delayed considerably. This will reduce welfare gains of member countries under the Asian track.

With respect to sectoral output adjustments, there appear to be no significant differences between the Asian-track and the TPP-track sequencings. In both FTA sequencings, correlations between sectoral adjustment rankings in 2020 and 2025 and those between rakings in 2025 and 2030 are relatively high, and both FTA sequencings would move the industrial structure within each member country closer to that which would prevail under global free trade.

In a revised version of this paper, an addition of the third FTA sequencing that delays an Asian-wide FTA several years relative to the EAFTA-CEPEA-FTAAP scenario, and implementations of several bilateral FTAs during the delayed FTAs would be beneficial. Since such scenario is more likely to be realized, the comparison with the TPPFTAAP scenario might be more helpful to policymakers.

\section{References}

Armington, P. (1969), A theory of demand for products distinguished by place of production. IMF Staff Papers, 16, 159-178.

Baldwin, R. E. (2008), Sequencing and depth of regional economic integration: Lessons for the Americas from Europe. World Economy, 31, 5-30.

Bernard, A. B. and J. B. Jensen (2004), Exporting and productivity in the USA. Oxford Review of Economic Policy, 20, 343-57.

Bond, E. W. (2008), Adjustment costs and the sequencing of trade liberalisation. World Economy, 31, 97-111.

Francois, J. F. and G. Wignaraja (2008), Economic implications of Asian integration. Global Economy Journal, 8(3), 1-46.

Hertel, T. W., ed. (1997), Global Trade Analysis: Modeling and Applications. Cambridge: Cambridge University Press. 
Ianchovichina, E. and R. McDougall (2001), Theoretical Structure of Dynamic GTAP. GTAP Technical Paper No. 17. West Lafayette: Center for Global Trade Analysis, Purdue University.

Kawai, M. and G. Wignaraja (2008), EAFTA or CEPEA: Which way forward? ASEAN Economic Bulletin, 25(2), 113-139.

Kreinin, M. and M. G. Plummer (2009), Optimal sequencing issues in real and monetary cooperation. Paper presented at the annual meeting of the American Economic Association, San Francisco, January 3-5.

Krueger, A. O. (1999), Are preferential trading arrangements trade-liberalizing or protectionist? Journal of Economic Perspectives, 13(4), 105-125.

Lee, H., R. F. Owen, and D. van der Mensbrugghe (2009), Regional integration in Asia and its effects on the EU and North America. Journal of Asian Economics, 20, 240-254.

Lee, H., D. Roland-Holst, and D. van der Mensbrugghe (2004), China's emergence in East Asia under alternative trading arrangements. Journal of Asian Economics, 15, 697-712.

Lee, H. and D. van der Mensbrugghe (2008), Regional integration, sectoral adjustments and natural groupings in East Asia. International Journal of Applied Economics, 5(2), 57-79.

Lloyd, P. J. and D. MacLaren (2004), Gains and losses from regional trading agreements: A survey. Economic Record, 80, 445-467.

Narayanan, B. and T. L. Walmsley, eds. (2008), Global Trade, Assistance, and Production: The GTAP 7 Data Base. West Lafayette: Center for Global Trade Analysis, Purdue University.

Panagariya, A. (2000), Preferential trade liberalization: The traditional theory and new development. Journal of Economic Literature, 38, 287-331.

Park, I. (2006), “East Asian regional trade agreements: Do they promote global free trade?” Pacific Economic Review, 11, 547-568.

Petri, P. A., M. G. Plummer, and F. Zhai (2011), Trans-Pacific Partnership and AsiaPacific Integration: A Quantitative Assessment. East-West Center Working Paper No. 119. October.

Urata, S. and K. Kiyota (2005), The impacts of an East Asia FTA on foreign trade in East Asia. In: T. Ito and A. Rose, eds., International Trade in East Asia. Chicago: University of Chicago Press. 
Table 1: Regional and sectoral aggregation

A. Regional aggregation

\begin{tabular}{rll}
\hline \multicolumn{1}{l}{ Country/region } & Corresponding economies/regions in the GTAP database \\
\hline 1 & Japan & Japan \\
2 & China & China, Hong Kong \\
3 & Korea & Korea \\
4 & Taiwan & Taiwan \\
5 & Singapore & Singapore \\
6 & Indonesia & Indonesia \\
7 & Malaysia & Malaysia \\
8 & Philippines & Philippines \\
9 & Thailand & Thailand \\
10 & Vietnam & Vietnam \\
11 & Rest of ASEAN & Cambodia, Laos, rest of Southeast Asia \\
12 & India & India \\
13 & Australia & Australia \\
14 & New Zealand & New Zealand \\
15 & United States & United States \\
16 & Canada & Canada \\
17 & Mexico & Mexico \\
18 & Chile & Chile \\
19 & Peru & Peru \\
20 & Russia & Russia \\
21 & EU-27 & Austria, Belgium, Bulgaria, Cyprus, Czech Republic, Denmark, Estonia, \\
& & Finland, France, Germany, Greece, Hungary, Ireland, Italy, Latvia, \\
& & Lithuania, Luxembourg, Malta, Netherlands, Poland, Portugal, Romania, \\
22 & Rest of world & Slovakia, Slovenia, Spain, Sweden, United Kingdom \\
\hline
\end{tabular}


Table 1 (continued)

B. Sectoral aggregation

\begin{tabular}{rll}
\hline & Sector & Corresponding commodities/sectors in the GTAP database \\
\hline 1 & Rice & Paddy rice, processed rice \\
2 & Other grains & Wheat, cereal grains nec \\
3 & Sugar & Sugar, sugar cane and sugar beet \\
4 & Other crops & Vegetables and fruits, oil seeds, plant-based fibers, crops nec \\
5 & Livestock & Cattle, sheep and goats, animal products nec, raw milk, wool \\
6 & Fossil fuels & Coal, oil, gas \\
7 & Natural resources & Forestry, fishing, minerals nec \\
8 & Meats & Cattle, sheep, goat, and horse meat products, meat products nec \\
9 & Dairy products & Dairy products \\
10 & Other food products & Vegetable oils, food products nec, beverages and tobacco products \\
11 & Textiles & Textiles \\
12 & Apparel & Wearing apparel, leather products \\
13 & Wood and paper & Wood products, paper products, publishing \\
14 & Petroleum products & Petroleum, coal products \\
15 & Chemical products & Chemical, rubber, plastic products \\
16 & Metal & Iron and steel, nonferrous metal, fabricated metal products \\
17 & Machinery & Machinery and equipment \\
18 & Electronic equipment & Electronic equipment \\
19 & Motor vehicles & Motor vehicles and parts \\
20 & Other transport equip. & Transport equipment nec \\
21 & Other manufactures & Mineral products nec, manufactures nec \\
22 & Construction and utilities & Construction, electricity, gas manufacture and distribution, water \\
23 & Trade & Trade \\
24 & Sea transport & Sea transport \\
25 & Air transport & Air transport \\
26 & Other transport & Other transport \\
27 & Financial services & Insurance, financial services nec \\
28 & Other private services & Communication, business services, recreation and other services \\
29 & Government services & Public administration and defense, education, health services \\
\hline & &
\end{tabular}

Source: GTAP database, version 7.1.

Note: nec $=$ not elsewhere classified. 
Table 2: Tariff rates on merchandise imports and tariff equivalents of nontariff barriers on services, 2004 (\%)

\begin{tabular}{|c|c|c|c|c|c|c|c|c|c|c|c|c|}
\hline & Sector & Japan & China & Korea & Taiwan & Singapore & Indonesia & Malaysia & $\begin{array}{l}\text { Philippine } \\
\text { s }\end{array}$ & Thailand & Vietnam & $\begin{array}{l}\text { Rest of } \\
\text { ASEAN }\end{array}$ \\
\hline 1 & Rice & 406.1 & 1.2 & 424.2 & 402.0 & 0.0 & 17.3 & 0.0 & 49.9 & 26.5 & 19.3 & 2.2 \\
\hline 2 & Other grains & 51.8 & 0.2 & 4.2 & 1.5 & 0.0 & 1.5 & 0.0 & 5.3 & 27.1 & 2.7 & 3.1 \\
\hline 3 & Sugar & 212.5 & 0.3 & 4.2 & 97.9 & 0.0 & 34.5 & 0.0 & 26.5 & 19.9 & 9.1 & 6.2 \\
\hline 4 & Other crops & 3.6 & 3.1 & 69.3 & 10.0 & 0.0 & 1.8 & 18.3 & 8.0 & 22.7 & 14.3 & 9.5 \\
\hline 5 & Livestock & 7.0 & 11.8 & 5.6 & 3.0 & 0.0 & 2.2 & 0.5 & 7.5 & 4.0 & 3.4 & 3.9 \\
\hline 6 & Fossil fuels & 0.0 & 0.2 & 4.2 & 4.9 & 0.0 & 0.0 & 1.8 & 3.1 & 0.0 & 2.2 & 0.1 \\
\hline 7 & Natural resources & 0.8 & 0.7 & 3.3 & 4.2 & 0.0 & 1.8 & 0.5 & 2.9 & 2.7 & 3.0 & 6.7 \\
\hline 8 & Meats & 49.9 & 5.0 & 31.7 & 31.5 & 0.0 & 2.7 & 0.7 & 16.9 & 38.1 & 18.6 & 9.7 \\
\hline 9 & Dairy products & 29.3 & 8.0 & 45.8 & 9.8 & 0.0 & 4.0 & 0.7 & 3.4 & 8.2 & 17.6 & 7.9 \\
\hline 10 & Other food products & 11.4 & 6.1 & 32.2 & 17.5 & 0.9 & 7.7 & 28.9 & 5.2 & 36.1 & 28.1 & 19.0 \\
\hline 11 & Textiles & 7.0 & 9.5 & 9.4 & 7.0 & 0.0 & 7.8 & 13.4 & 6.2 & 19.7 & 30.7 & 10.9 \\
\hline 12 & Apparel & 10.5 & 10.0 & 10.3 & 8.6 & 0.0 & 6.4 & 13.1 & 11.9 & 15.6 & 24.0 & 16.1 \\
\hline 13 & Wood and paper & 1.0 & 3.6 & 3.2 & 2.4 & 0.0 & 3.4 & 6.4 & 5.5 & 15.8 & 11.2 & 5.6 \\
\hline 14 & Petroleum products & 2.0 & 5.4 & 5.1 & 4.9 & 0.0 & 2.0 & 6.7 & 2.4 & 1.1 & 14.5 & 3.2 \\
\hline 15 & Chemical products & 0.9 & 8.7 & 6.3 & 3.1 & 0.0 & 4.4 & 4.2 & 4.8 & 11.1 & 4.6 & 5.4 \\
\hline 16 & Metal & 0.6 & 4.7 & 3.2 & 2.3 & 0.0 & 5.1 & 6.4 & 3.9 & 8.0 & 4.5 & 3.7 \\
\hline 17 & Machinery & 0.1 & 6.5 & 6.1 & 2.6 & 0.0 & 3.2 & 4.3 & 3.0 & 7.4 & 6.3 & 5.9 \\
\hline 18 & Electronic equipment & 0.0 & 1.7 & 1.0 & 0.4 & 0.0 & 1.5 & 1.0 & 0.2 & 3.9 & 7.0 & 7.2 \\
\hline 19 & Motor vehicles & 0.0 & 20.1 & 8.0 & 31.4 & 0.0 & 13.5 & 47.4 & 10.4 & 28.6 & 33.8 & 37.9 \\
\hline 20 & Other transport equip. & 0.0 & 2.9 & 1.9 & 2.1 & 0.0 & 3.9 & 3.8 & 6.4 & 4.9 & 12.8 & 7.8 \\
\hline 21 & Other manufactures & 1.0 & 6.0 & 8.0 & 5.5 & 0.0 & 6.6 & 8.9 & 6.9 & 9.1 & 18.2 & 8.8 \\
\hline 22 & Construction and utilities & 34.5 & 55.7 & 54.3 & 44.0 & 0.0 & 178.8 & 63.6 & 138.0 & 97.3 & 152.2 & 66.3 \\
\hline 23 & Trade & 37.9 & 205.2 & 58.1 & 47.6 & 0.0 & 185.0 & 67.5 & 143.4 & 110.0 & 157.9 & 57.5 \\
\hline 24 & Sea transport & 7.6 & 29.0 & 23.4 & 15.3 & 0.0 & 122.6 & 30.8 & 90.0 & 64.0 & 101.4 & 5.3 \\
\hline 25 & Air transport & 31.5 & 109.0 & 50.8 & 40.8 & 0.0 & 171.8 & 59.7 & 132.1 & 100.3 & 146.0 & 49.2 \\
\hline 26 & Other transport & 32.9 & 134.6 & 52.4 & 42.3 & 0.0 & 174.7 & 61.4 & 134.6 & 102.4 & 148.6 & 22.4 \\
\hline 27 & Financial services & 28.2 & 138.1 & 47.8 & 37.6 & 0.0 & 163.5 & 56.9 & 127.6 & 99.2 & 140.0 & 30.6 \\
\hline 28 & Other private services & 27.3 & 128.1 & 45.6 & 36.0 & 0.0 & 161.0 & 56.1 & 124.4 & 93.0 & 138.1 & 11.9 \\
\hline 29 & Government services & 37.9 & 138.3 & 58.1 & 47.6 & 0.0 & 185.0 & 67.5 & 143.4 & 110.0 & 157.9 & 37.7 \\
\hline
\end{tabular}


Table 2 (continued)

\begin{tabular}{|c|c|c|c|c|c|c|c|c|c|c|c|c|}
\hline & Sector & India & Australia & $\begin{array}{c}\text { New } \\
\text { Zealand }\end{array}$ & $\begin{array}{l}\text { United } \\
\text { States }\end{array}$ & Canada & Mexico & Chile & Peru & Russia & EU-27 & $\begin{array}{c}\text { Rest of } \\
\text { world }\end{array}$ \\
\hline 1 & Rice & 43.8 & 0.0 & 0.0 & 3.3 & 0.0 & 0.1 & 5.2 & 6.3 & 8.2 & 40.0 & 14.9 \\
\hline 2 & Other grains & 14.8 & 0.0 & 0.0 & 0.1 & 0.0 & 5.5 & 2.0 & 11.6 & 1.1 & 6.5 & 14.4 \\
\hline 3 & Sugar & 84.3 & 0.0 & 0.0 & 39.1 & 0.6 & 0.0 & 6.0 & 9.4 & 25.8 & 53.4 & 13.4 \\
\hline 4 & Other crops & 32.8 & 0.6 & 0.0 & 3.2 & 0.2 & 1.5 & 0.9 & 9.3 & 6.2 & 5.3 & 11.5 \\
\hline 5 & Livestock & 12.5 & 0.0 & 0.0 & 0.1 & 14.6 & 1.2 & 0.5 & 9.2 & 5.6 & 0.8 & 5.6 \\
\hline 6 & Fossil fuels & 11.1 & 0.0 & 0.0 & 0.2 & 0.0 & 0.0 & 2.4 & 10.5 & 0.0 & 0.0 & 1.4 \\
\hline 7 & Natural resources & 12.4 & 0.1 & 0.0 & 0.1 & 0.0 & 3.5 & 0.6 & 6.8 & 2.3 & 0.3 & 2.2 \\
\hline 8 & Meats & 25.9 & 0.4 & 0.7 & 5.5 & 34.8 & 1.0 & 1.3 & 12.7 & 15.2 & 8.3 & 28.0 \\
\hline 9 & Dairy products & 34.7 & 3.4 & 13.6 & 25.6 & 106.1 & 17.1 & 1.6 & 18.4 & 6.8 & 2.2 & 13.1 \\
\hline 10 & Other food products & 85.5 & 1.7 & 5.1 & 3.4 & 9.0 & 3.9 & 1.3 & 6.2 & 11.2 & 2.5 & 16.6 \\
\hline 11 & Textiles & 16.4 & 12.5 & 5.1 & 7.3 & 5.4 & 3.3 & 3.8 & 14.2 & 11.0 & 2.2 & 12.5 \\
\hline 12 & Apparel & 12.3 & 16.8 & 11.1 & 10.0 & 11.1 & 10.9 & 4.9 & 18.5 & 17.6 & 3.3 & 12.7 \\
\hline 13 & Wood and paper & 13.2 & 3.1 & 1.4 & 0.2 & 0.5 & 1.8 & 1.0 & 7.7 & 10.9 & 0.1 & 6.8 \\
\hline 14 & Petroleum products & 11.7 & 0.0 & 2.3 & 1.4 & 0.7 & 1.4 & 1.3 & 10.7 & 2.1 & 0.6 & 7.9 \\
\hline 15 & Chemical products & 14.3 & 2.8 & 1.7 & 1.4 & 0.6 & 2.0 & 1.6 & 6.9 & 9.3 & 0.4 & 5.5 \\
\hline 16 & Metal & 15.7 & 3.1 & 1.9 & 1.0 & 0.4 & 2.8 & 1.6 & 7.6 & 7.2 & 0.4 & 5.5 \\
\hline 17 & Machinery & 14.1 & 3.3 & 2.7 & 1.0 & 0.4 & 3.2 & 1.4 & 7.4 & 7.1 & 0.4 & 5.9 \\
\hline 18 & Electronic equipment & 2.6 & 0.8 & 0.4 & 0.3 & 0.0 & 1.7 & 2.0 & 8.0 & 7.3 & 0.7 & 5.2 \\
\hline 19 & Motor vehicles & 24.6 & 8.4 & 7.3 & 1.2 & 0.9 & 3.5 & 2.3 & 8.9 & 14.7 & 1.0 & 10.1 \\
\hline 20 & Other transport equip. & 10.0 & 0.8 & 0.6 & 0.5 & 1.1 & 5.4 & 0.8 & 8.5 & 10.6 & 0.7 & 5.2 \\
\hline 21 & Other manufactures & 14.8 & 3.4 & 5.1 & 1.7 & 0.9 & 8.1 & 2.7 & 9.5 & 13.5 & 0.7 & 7.3 \\
\hline 22 & Construction and utilities & 273.5 & 33.4 & 7.6 & 0.0 & 25.9 & 104.6 & 45.4 & 82.1 & 115.5 & 13.9 & 69.3 \\
\hline 23 & Trade & 299.2 & 36.4 & 9.9 & 0.0 & 35.0 & 110.0 & 55.6 & 86.1 & 130.9 & 16.0 & 80.3 \\
\hline 24 & Sea transport & 211.7 & 6.5 & 0.0 & 0.0 & 5.4 & 64.0 & 21.5 & 45.3 & 80.3 & 2.8 & 27.9 \\
\hline 25 & Air transport & 280.7 & 30.1 & 4.9 & 0.0 & 28.7 & 100.3 & 48.4 & 77.5 & 120.2 & 14.2 & 82.9 \\
\hline 26 & Other transport & 284.7 & 31.5 & 6.0 & 0.0 & 30.1 & 102.4 & 50.0 & 79.4 & 122.6 & 12.6 & 63.9 \\
\hline 27 & Financial services & 269.6 & 27.1 & 2.7 & 0.0 & 26.2 & 99.1 & 45.0 & 75.8 & 114.8 & 7.8 & 69.7 \\
\hline 28 & Other private services & 265.1 & 26.9 & 1.5 & 0.0 & 24.9 & 99.6 & 43.2 & 70.9 & 113.3 & 10.0 & 63.5 \\
\hline 29 & Government services & 299.2 & 36.4 & 9.9 & 0.0 & 35.0 & 110.0 & 55.6 & 86.1 & 130.9 & 16.8 & 83.0 \\
\hline
\end{tabular}

Source: Sectors 1-21: GTAP database, version 7.1. Sectors 22-29: Calculated based on the estimates of tariff equivalents of nontariff barriers on services by Wang et al. (2009). 
Table 3: The welfare effects of alternative scenarios

(Percentage point deviations in equivalent variation from the baseline)

\begin{tabular}{|c|c|c|c|c|c|c|}
\hline & \multicolumn{3}{|c|}{ EAFTA-CEPEA-FTAAP Scenario } & \multicolumn{3}{|c|}{ TPP-FTAAP Scenario } \\
\hline & 2020 & 2025 & 2030 & 2020 & 2025 & 2030 \\
\hline Japan & 0.9 & 1.1 & 1.4 & 0.4 & 0.9 & 1.8 \\
\hline China & 3.9 & 4.2 & 4.8 & -0.2 & 0.5 & 2.5 \\
\hline Korea & 6.0 & 6.0 & 6.0 & 2.8 & 4.3 & 7.5 \\
\hline Taiwan & -1.5 & -0.2 & 4.5 & -0.1 & 1.9 & 6.8 \\
\hline Singapore & 4.0 & 3.8 & 3.5 & 0.1 & 0.0 & 0.1 \\
\hline Indonesia & 5.0 & 5.3 & 6.6 & -0.1 & 0.5 & 3.8 \\
\hline Malaysia & 2.9 & 3.7 & 4.9 & 2.1 & 2.1 & 2.1 \\
\hline Philippines & 2.4 & 2.0 & 2.8 & 0.0 & 0.3 & 2.0 \\
\hline Thailand & 3.8 & 4.4 & 6.1 & -0.4 & 0.1 & 2.3 \\
\hline Vietnam & 7.7 & 9.8 & 13.5 & 5.5 & 5.5 & 5.6 \\
\hline Rest ofASEAN & 1.7 & 2.5 & 2.9 & -0.1 & 0.1 & 0.6 \\
\hline India & 2.5 & 6.2 & 8.4 & -0.1 & -0.4 & -0.9 \\
\hline Australia & 1.7 & 3.9 & 4.1 & 0.6 & 1.1 & 2.6 \\
\hline New Zealand & 0.6 & 2.8 & 3.5 & 0.8 & 2.1 & 4.9 \\
\hline United States & -0.1 & 0.0 & 0.6 & 0.2 & 0.4 & 0.8 \\
\hline Canada & 0.1 & 0.8 & 2.2 & 0.6 & 1.2 & 1.8 \\
\hline Mexico & 0.1 & 1.3 & 3.6 & 1.1 & 2.1 & 2.6 \\
\hline Chile & -0.3 & 0.5 & 4.3 & 1.3 & 2.4 & 5.3 \\
\hline Peru & 0.3 & 0.7 & 1.9 & 0.6 & 0.9 & 1.7 \\
\hline Russia & 0.4 & 2.4 & 7.8 & -0.1 & 1.4 & 6.4 \\
\hline EU-27 & -0.3 & -0.5 & -0.7 & 0.0 & -0.1 & -0.3 \\
\hline Rest of world & 0.3 & 0.6 & 0.7 & -0.1 & -0.2 & -0.3 \\
\hline
\end{tabular}

Definitions of scenarios:

EAFTA-CEPEA-FTAAP scenario: EU-Korea FTA, Korea-US FTA, and ASEAN+3 FTA over the period 2013-2016, ASEAN+6 FTA over the period 2017-2022, and FTAAP over the period 2023-2030. TPP-FTAAP scenario: EU-Korea FTA, Korea-US FTA, and TPP9 over the period 2013-2016, TPP13 over the period 2017-2022, and FTAAP over the period 2023-2030.

Source: Model simulations. 
Table 4: Spearman rank correlation coefficients between sectoral adjustment rankings in 2020-2025 and 2025-2030 for each scenario, and those between rankings in each scenario and GTL for the year 2030

\begin{tabular}{|c|c|c|c|}
\hline & $\begin{array}{l}\text { Between rankings } \\
\text { in } 2020 \text { and } 2025\end{array}$ & $\begin{array}{l}\text { Between rankings } \\
\text { in } 2025 \text { and } 2030\end{array}$ & $\begin{array}{l}\text { Between rankings } \\
\text { in each scenario } \\
\text { and GTL, } 2030\end{array}$ \\
\hline \multicolumn{4}{|c|}{ EAFTA-CEPEA-FTAAP Scenario } \\
\hline Japan & 0.90 & 0.97 & 0.80 \\
\hline China & 0.80 & 0.83 & 0.93 \\
\hline Korea & 0.91 & 0.97 & 0.96 \\
\hline Singapore & 0.92 & 0.94 & 0.56 \\
\hline Indonesia & 0.96 & 0.98 & 0.98 \\
\hline Malaysia & 0.92 & 0.90 & 0.85 \\
\hline Philippines & 0.88 & 0.83 & 0.80 \\
\hline Thailand & 0.98 & 0.91 & 0.91 \\
\hline Vietnam & 0.94 & 0.93 & 0.95 \\
\hline Rest ofASEAN & 0.82 & 0.85 & 0.69 \\
\hline India & 0.80 & 0.88 & 0.92 \\
\hline Australia & 0.94 & 0.76 & 0.88 \\
\hline New Zealand & 0.84 & 0.85 & 0.90 \\
\hline United States & 0.52 & 0.64 & 0.80 \\
\hline \multicolumn{4}{|c|}{ TPP-FTAAP Scenario } \\
\hline Japan & 0.77 & 0.84 & 0.64 \\
\hline China & 0.79 & 0.76 & 0.87 \\
\hline Korea & 0.90 & 0.91 & 0.89 \\
\hline Singapore & 0.86 & 0.74 & 0.66 \\
\hline Indonesia & 0.65 & 0.85 & 0.95 \\
\hline Malaysia & 0.96 & 0.95 & 0.84 \\
\hline Philippines & 0.44 & 0.94 & 0.80 \\
\hline Thailand & 0.90 & 0.83 & 0.86 \\
\hline Vietnam & 0.92 & 0.95 & 0.94 \\
\hline Rest ofASEAN & 0.23 & 0.65 & 0.37 \\
\hline India & 0.23 & 0.66 & 0.34 \\
\hline Australia & 0.83 & 0.84 & 0.73 \\
\hline New Zealand & 0.80 & 0.92 & 0.86 \\
\hline United States & 0.99 & 0.93 & 0.72 \\
\hline
\end{tabular}

Source: The authors' calculation based on the results of model simulations. 
Appendix Table: Projected trade shares in the baseline, 2013 (\%)

\begin{tabular}{|c|c|c|c|c|c|c|c|}
\hline \multirow[b]{2}{*}{ Exporters } & \multicolumn{7}{|c|}{ Export shares by destination } \\
\hline & China & U.S. & ASEAN+3 & ASEAN+6 & ТPР-9 & TPР-13 & FTAAP \\
\hline Japan & 25.0 & 12.8 & 46.6 & 49.8 & 21.6 & 30.9 & 72.2 \\
\hline China & - & 18.4 & 31.8 & 35.3 & 26.5 & 41.7 & 58.4 \\
\hline Korea & 36.6 & 9.9 & 52.9 & 55.8 & 17.5 & 24.6 & 70.5 \\
\hline Taiwan & 50.5 & 9.7 & 68.6 & 70.5 & 17.5 & 26.3 & 81.1 \\
\hline Singapore & 23.4 & 5.9 & 56.5 & 62.4 & 19.7 & 27.7 & 67.4 \\
\hline Indonesia & 21.1 & 6.0 & 53.6 & 67.5 & 20.1 & 37.6 & 67.4 \\
\hline Malaysia & 29.6 & 8.7 & 58.5 & 66.3 & 23.1 & 34.0 & 73.9 \\
\hline Philippines & 26.1 & 10.0 & 58.9 & 60.6 & 24.9 & 42.7 & 78.6 \\
\hline Thailand & 26.8 & 6.8 & 59.5 & 63.4 & 19.6 & 35.1 & 70.0 \\
\hline Vietnam & 33.2 & 9.6 & 58.9 & 63.7 & 19.6 & 34.5 & 75.2 \\
\hline Rest of ASEAN & 13.5 & 11.8 & 58.8 & 71.6 & 23.2 & 45.0 & 78.8 \\
\hline India & 15.8 & 10.2 & 28.0 & 29.0 & 15.7 & 20.9 & 42.7 \\
\hline Australia & 24.6 & 5.4 & 54.5 & 65.1 & 13.8 & 35.7 & 68.2 \\
\hline New Zealand & 12.6 & 10.0 & 35.0 & 53.5 & 31.9 & 48.3 & 67.2 \\
\hline United States & 9.3 & - & 25.0 & 28.4 & 7.2 & 37.3 & 52.1 \\
\hline Canada & 7.1 & 65.0 & 12.9 & 14.1 & 67.0 & 71.8 & 80.7 \\
\hline Mexico & 2.1 & 70.2 & 4.1 & 5.6 & 71.6 & 75.3 & 78.0 \\
\hline Chile & 13.8 & 11.0 & 32.0 & 34.9 & 16.3 & 34.7 & 52.7 \\
\hline Peru & 29.1 & 13.7 & 39.0 & 40.5 & 22.2 & 34.0 & 65.6 \\
\hline Russia & 12.2 & 4.6 & 18.2 & 19.7 & 6.0 & 10.2 & 24.8 \\
\hline EU-27 & 4.0 & 6.6 & 8.8 & 11.0 & 9.4 & 12.7 & 20.2 \\
\hline Rest of world & 13.8 & 10.7 & 29.0 & 34.7 & 15.1 & 26.6 & 47.2 \\
\hline
\end{tabular}


Appendix Table (continued)

\begin{tabular}{|c|c|c|c|c|c|c|c|}
\hline \multirow[b]{2}{*}{ Importers } & \multicolumn{7}{|c|}{ Import shares by origin } \\
\hline & China & U.S. & ASEAN+3 & ASEAN+6 & ТPР-9 & TPP-13 & FTAAP \\
\hline Japan & 23.9 & 16.4 & 39.0 & 44.4 & 25.9 & 31.6 & 65.4 \\
\hline China & - & 9.3 & 43.4 & 48.4 & 20.9 & 43.5 & 68.6 \\
\hline Korea & 16.7 & 15.5 & 42.8 & 47.1 & 24.9 & 41.8 & 66.9 \\
\hline Taiwan & 14.6 & 16.5 & 50.4 & 53.2 & 23.1 & 51.1 & 72.1 \\
\hline Singapore & 15.4 & 16.5 & 43.0 & 46.3 & 26.7 & 38.7 & 65.7 \\
\hline Indonesia & 20.2 & 7.1 & 59.7 & 66.5 & 28.0 & 45.8 & 72.6 \\
\hline Malaysia & 19.3 & 12.4 & 59.8 & 64.2 & 27.3 & 46.6 & 79.5 \\
\hline Philippines & 21.3 & 9.5 & 59.9 & 63.5 & 21.4 & 44.6 & 79.6 \\
\hline Thailand & 16.7 & 7.7 & 55.6 & 59.1 & 19.2 & 44.0 & 67.0 \\
\hline Vietnam & 31.9 & 5.0 & 69.6 & 73.1 & 18.0 & 36.6 & 83.0 \\
\hline Rest of ASEAN & 25.6 & 3.4 & 79.6 & 83.7 & 28.0 & 36.9 & 86.9 \\
\hline India & 8.5 & 8.0 & 26.6 & 30.6 & 18.5 & 25.2 & 42.3 \\
\hline Australia & 19.0 & 18.2 & 44.6 & 49.6 & 30.3 & 43.9 & 69.6 \\
\hline New Zealand & 12.6 & 14.0 & 33.9 & 55.7 & 40.2 & 53.8 & 71.5 \\
\hline United States & 20.1 & - & 33.8 & 36.2 & 3.7 & 39.2 & 63.7 \\
\hline Canada & 8.1 & 68.1 & 13.1 & 14.4 & 69.7 & 74.8 & 84.5 \\
\hline Mexico & 9.1 & 66.3 & 15.5 & 16.3 & 68.3 & 74.1 & 85.1 \\
\hline Chile & 9.6 & 19.3 & 18.4 & 20.0 & 24.0 & 34.0 & 46.0 \\
\hline Peru & 8.1 & 27.4 & 15.7 & 17.4 & 34.2 & 43.5 & 54.2 \\
\hline Russia & 9.1 & 7.6 & 17.1 & 18.8 & 9.4 & 15.9 & 26.3 \\
\hline EU-27 & 9.2 & 8.9 & 15.5 & 17.3 & 11.3 & 16.2 & 29.7 \\
\hline Rest of world & 9.7 & 14.6 & 19.5 & 23.7 & 18.0 & 26.7 & 42.5 \\
\hline
\end{tabular}

Source: Baseline simulation. 